\title{
Temporal variation in the arsenic and metal accumulation in the maritime pine tree grown on contaminated soils
}

\author{
P. J. C. Favas · J. Pratas • M. N. V. Prasad
}

Received: 13 November 2011/Revised: 28 April 2012/Accepted: 9 October 2012/Published online: 31 October 2012

(C) CEERS, IAU 2012

\begin{abstract}
The uptake of arsenic and other metals (iron, manganese, copper, zinc, lead, nickel and tungsten) by Pinus pinaster Aiton (the maritime pine tree) growing in soils and tailings around an abandoned mine (northern Portugal) was investigated. Aerial parts of Pinus pinaster trees were sampled from three substrate areas: a background area, in mine contaminated soils and in tailings. Vegetation material was separated into needles and stems and subdivided into tissues of different maturities (1-, 2-, 3- and 4-years-old). The sampling of the substrate in each area was also undertaken. In general, vegetation concentrations were strongly related to substrate concentrations. The results show that the contents of several elements depend as much on the plant organ as on the age of the tissue. For the researched elements, this species shows a great variability in behavior depending on the age of the organ. The data indicate that the older needles constitute the best samples for use in a conjunct biogeochemical analysis of these elements.
\end{abstract}

P. J. C. Favas $(\square)$

Department of Geology, School of Life Sciences and the Environment, University of Trás-os-Montes e Alto Douro, 5001-801 Vila Real, Portugal

e-mail: pjcf@utad.pt

P. J. C. Favas · J. Pratas

IMAR-CMA Marine and Environmental Research Centre, Faculty of Sciences and Technology, University of Coimbra, 3001-401 Coimbra, Portugal

J. Pratas

Department of Earth Sciences, Faculty of Sciences and Technology, University of Coimbra, 3001-401 Coimbra, Portugal

M. N. V. Prasad

Department of Plant Sciences, University of Hyderabad, Hyderabad 500046, India
Keywords Bioaccumulation - Bioindicator . Biogeochemistry · Biomonitoring · Mine tailings · Pinus pinaster Aiton. · Vale das Gatas mine

\section{Introduction}

The use of vegetal species as contamination indicators usually takes into account the abilities of these species to accumulate heavy metals and other chemical elements or compounds (e.g., Kabata-Pendias 2010; Wittig 1993). Meanwhile, this accumulation generally does not change linearly with time, and varies either seasonally or with the age of the sampled organs (Kuang et al. 2007; Pratas et al. 2004, 2005). In the first case of variation, the solution to characterizing the variation of the accumulation of compounds lies in the orientation of the sampling campaign for a certain period of time, and in the second case of variation the introduction of the factor "age of the material collected" reveals the need for detailed studies.

During the last two decades, there has been an increase in the study of tree leaves as bioaccumulators of trace elements in the vicinity of industrial plants (e.g., Dmuchowski et al. 2011; Oliva and Mingorance 2006; Rodriguez et al. 2012) and in urban environments (e.g., Baycu et al. 2006; Guéguen et al. 2012; Kord et al. 2010; Liu et al. 2007; Sawidis et al. 2011). In addition, although not as numerous, there have also been studies of tree leaves as bioaccumulators in rural and background areas (e.g., Chiarenzelli et al. 2001; Coşkun 2006). Besides the potential use for biogeochemical prospecting and environmental biomonitoring, those metal-tolerant perennials plants with high biomass and bioproductivity can also be useful in phytostabilization and mine restoration (Hooper and Vitousek 1997; Pratas et al. 2005).

According to Aboal et al. (2004), there is a large amount of information available on the concentrations of trace 
elements in the leaves and needles of trees commonly used as biomonitors such as Pinus sylvestris, Picea abies and Quercus ilex. All of these species are common in either northern Europe or southern Europe but are not found at more temperate latitudes; therefore, similar alternative species must be selected to allow studies of this type in these areas. According to Aboal et al. (2004), from among the possible alternatives, Quercus robur and Pinus pinaster are good candidates because of their distribution; however, to date, biomonitoring studies involving these species have been very limited.

Bargagli (1993) used the needles of Pinus pinaster as biomonitors of natural and anthropogenic emissions of mercury (Hg). Aboal et al. (2004) used the needles of Pinus pinaster as biomonitors of airborne trace element pollution. Pinus pinaster needles have been reported to accumulate aluminum (Al), arsenic (As), cadmium $(\mathrm{Cd})$, copper $(\mathrm{Cu})$, chromium $(\mathrm{Cr})$, iron $(\mathrm{Fe}), \mathrm{Hg}$, manganese $(\mathrm{Mn})$, nickel $(\mathrm{Ni})$, lead $(\mathrm{Pb})$ and zinc $(\mathrm{Zn})$. Pratas et al. (2004, 2005) studied the needles and stems of Pinus pinaster as the indicators for delineating areas of anomalous soil composition in the biogeochemical prospecting of As, antimony (Sb) and tungsten (W).

In biogeochemical studies, the application of the biological absorption coefficient (BAC) is very common as a bioaccumulation indicator of the chemical elements. The $\mathrm{BAC}$ is one of the most important biogeochemical parameters for the verification of the relationships between plants and soil for each element, and Kovalevskii (1979) and Brooks (1983) defined the BAC as the relationship between the concentration of an element in the ashes or in the dry plant material, $C \mathrm{p}$, and the concentration of the same element in the substrate, $C \mathrm{~s},(\mathrm{BAC}=C \mathrm{p} / C \mathrm{~s})$. Nagaraju and Karimulla (2002) reported that Perelman classified the values of BAC into five groups (intensive absorption, BAC 10-100; strong absorption, BAC 1-10; intermediate absorption, BAC 0.1-1; weak absorption, BAC 0.01-0.1; and very weak absorption, BAC 0.001-0.01).

The objective of the present study was to evaluate the temporal variation of As and heavy metals ( $\mathrm{Fe}, \mathrm{Mn}, \mathrm{Cu}$, $\mathrm{Zn}, \mathrm{Pb}, \mathrm{Ni}$ and $\mathrm{W}$ ) in tissues of different ages of maritime pine trees (Pinus pinaster Aiton) grown on mine tailings and soils in the area surrounding the abandoned Vale das Gatas mine (N Portugal).

\section{Studied area}

The Vale das Gatas mine is located in the district of Vila Real in northern Portugal (Fig. 1). The geological units that emerge in this sector are metasedimentary rocks (SchistMetagraywacke Complex), Hercynian granites and veinous rocks (mineralized and non-mineralized) (Fig. 1).
The Vale das Gatas granite (VGG) is affected by fracture families that are distributed according to preferential directions. Some of these fractures are filled with quartz, aplite and pegmatite, which support $\mathrm{W}$, tin (Sn) and sulfide mineralizations.

The paragenesis defined for the deposition stages indicated that wolframite is the most plentiful mineral; cassiterite, scheelite, several sulfides (pyrite, chalcopyrite, sphalerite, galena, arsenopyrite, pyrrhotite, stannite, covellite, marcasite), silver (Ag), $\mathrm{Pb}$ and bismuth (Bi) sulfosalts and native $\mathrm{Bi}$ were also present. The minerals that support mineralization are essentially quartz, fluorite and muscovite.

Topographic elevations in the Vale das Gatas mine area vary between 310 and $815 \mathrm{~m}$. In recent years, the average annual precipitation was $816 \mathrm{~mm}$ and the average annual temperature was $13.9{ }^{\circ} \mathrm{C}$. The annual precipitation in the area varied from a minimum of $12.8 \mathrm{~mm}$ in August to a maximum of $142 \mathrm{~mm}$ in January and the temperature varies between $5.4{ }^{\circ} \mathrm{C}$ in January and $23^{\circ} \mathrm{C}$ in August. In this region, the characteristic soil units are Leptosols, Cambisols and Anthrosols. The dominant soil unit of the studied area is the Leptosol type, which consists of soils whose principal characteristic is the presence of bedrock at $20 \mathrm{~cm}$ below the surface. These soils are divided into a distric (acid) sub-unit associated with the metasedimentary rocks and an umbric (acid and organic-rich) sub-unit associated with granitic rocks.

The Vale das Gatas mine, exploited in the past by the Romans, was in regular operation between 1883 and 1992. The mining operation was conducted underground. Wolframite and scheelite were mined for $\mathrm{W}$, and cassiterite was mined for Sn. However, there has been no mining in the area since 1992, and the mine was abandoned without any environmental remediation. The tailings, which still contain metals, were deposited on the ground. Exposure of these materials to air and water produces acidic water, facilitating the release of contaminants into the surrounding environments (Ávila et al. 2005; Favas 2002; Salgueiro et al. 2008). In this mine site, tailings and acid drainage from the mine galleries (Fig. 2) are the major sources of metallic pollution. The area is crossed by a stream which contributes to the dispersion of contamination.

\section{Materials and methods}

Sampling and sample preparation

The samples of Pinus pinaster were collected in five sampling areas: three sampling areas outside of the mine influence ( $A, B$ and $C$ ); in one area (D) in which contamination resulting from the dispersion of the tailings was 

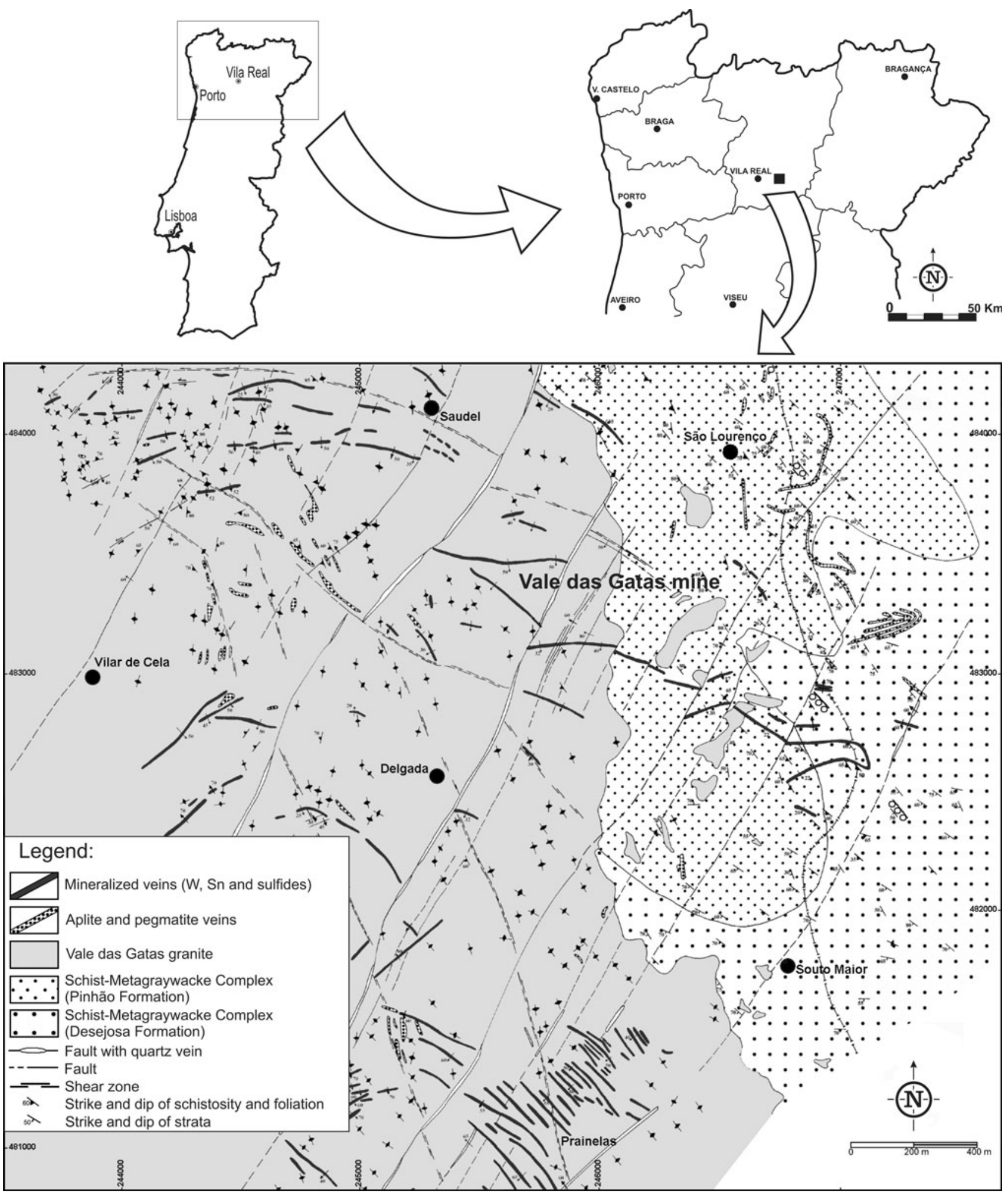

Fig. 1 Location of the Vale das Gatas mine area on the map of Portugal and a simplified geological map of the abandoned Vale das Gatas mine

previously detected (Favas 2002) and in one area with tailings (Fig. 2). The sampling methodology followed the orientations defined by Brooks (1983), Özdemir (2005) and
Sun et al. (2009). The needles, stems and rooting soils of Pinus pinaster were collected at the five locations in late July and early August, during the dry season of the year. 
Fig. 2 Location of the Vale das Gatas mine area on the map of Portugal and a simplified topographical map of the sampling points (area A: $n=11$; area B: $n=14$; area C: $n=10$; area D: $n=22$; tailings: $n=12$ )

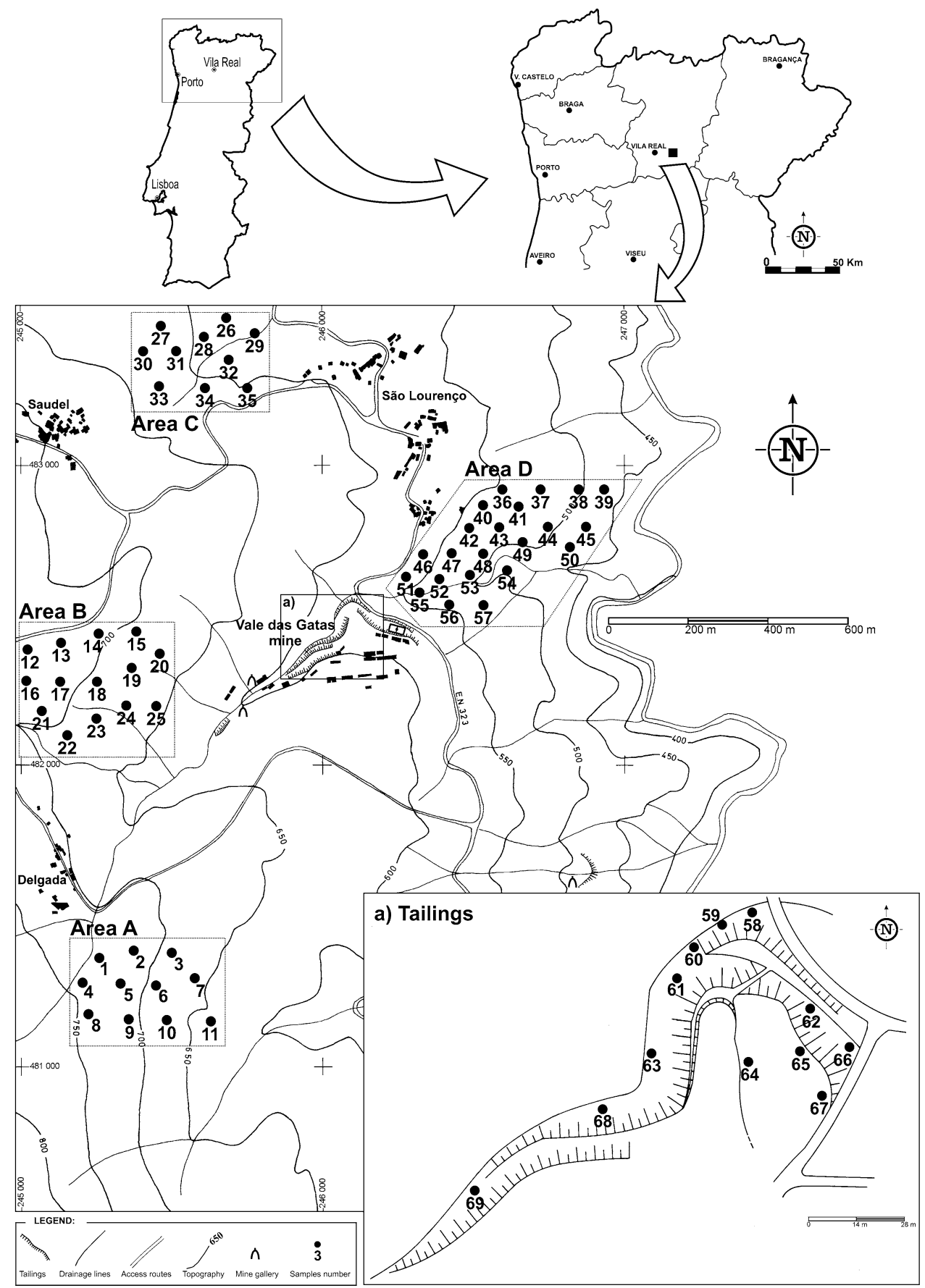

The pine samples were collected from trees of similar size and about 10-15 years old. Needles and stems were collected from outer branches of the middle canopy at south, west, east, and north directions and then were homogeneously mixed. When the vegetal material was sampled, we separated the different organs (stems and needles) and the tissues by age. We collected stems with 1-, 2-, 3- and 4-years-old and needles with 1-, 2- and 3-years-old. The samples were separately collected into clean cellulose bags and brought to the laboratory on the same day. Each soil or tailings sample weighs about $5 \mathrm{~kg}$, and consists of a homogenate of four subsample points collected from the rooting zone $(0-20 \mathrm{~cm}$ depth) at the same four directions with a distance of $80 \mathrm{~cm}$ away from the sample tree. The total number of sampling locations was 69 distributed as follows: 11 locations in the area $\mathrm{A} ; 14$ locations in the area $\mathrm{B} ; 10$ locations in the area $\mathrm{C} ; 22$ locations in the area $\mathrm{D}$; and 12 locations in the tailings. This resulted in 
69 soil/tailings samples and 69 sampled pine trees. We collected 483 plant tissues (stems and needles with different ages).

In the laboratory, the vegetal material was washed thoroughly, first in running water and then in distilled water, and then dried in a glasshouse at a temperature of $50{ }^{\circ} \mathrm{C}$. When dry, the material was milled into a homogenous powder. Soil and tailings samples were oven-dried at a constant temperature of $40{ }^{\circ} \mathrm{C}$, manually homogenized and quartered. Two equivalent fractions were obtained from each quartered sample. One fraction was used for the determination of physico-chemical properties, and the other fraction was used for chemical analysis. The samples for chemical analysis were sieved using a $2 \mathrm{~mm}$ mesh sieve to remove plant matter, and subsequently screened to pass through a $250 \mu \mathrm{m}$ screen (Brooks 1983); this fraction was then milled to below $74 \mu \mathrm{m}$.

\section{Analytical methods}

The main physico-chemical properties of the samples $(<2 \mathrm{~mm}$ fraction) were characterized at the UTAD Soil Analysis Laboratory (Portugal) using the following methods: the $\mathrm{pH}$ was determined in water extracts $(1: 2.5 \mathrm{v} / \mathrm{v})$; organic carbon was determined with an elemental analyzer (Primacs SCN Analyzer, Skalar); and a conversion factor of 1.724 was used to convert organic carbon (C) into organic matter based on the assumption that organic matter contains $58 \%$ organic C (Nelson and Sommers 1996). The chemical analyses were performed at the Chemical Laboratory at the Department of Earth Sciences, University of Coimbra (Portugal) using current analytical methods. Dried soil/tailings samples $(1.0 \mathrm{~g})$ were placed in Teflon crucibles. Ten $\mathrm{ml}$ of concentrated nitric acid $\left(\mathrm{HNO}_{3}\right)$ was added to the samples, which were then heated in a water bath until dry. Then $5 \mathrm{ml}$ of perchloric acid $\left(\mathrm{HClO}_{4}\right)$ and $10 \mathrm{ml}$ of hydrofluoric acid (HF) was added and the evaporation was repeated. The residue was dissolved in $10 \mathrm{ml}$ of hydrochloric acid $(\mathrm{HCl})$ and diluted to $100 \mathrm{ml}$ by adding deionized water (Walsh et al. 1997). Heavy metal (Fe, Mn, $\mathrm{Cu}, \mathrm{Zn}, \mathrm{Pb}, \mathrm{Ni}$ ) concentrations were measured by the atomic absorption spectrophotometry (AAS, Perkin Elmer 2380). To determine the concentrations of As, a hydride generation system (HGS) linked to an atomic absorption device was used.

As for the plant material, dried samples $(5.0 \mathrm{~g})$ were placed in porcelain crucibles and reduced to ash in a muffle furnace over $12 \mathrm{~h}$ to a maximum temperature of $450{ }^{\circ} \mathrm{C}$. Ash samples were cooled and weighed. Ten $\mathrm{ml}$ of $\mathrm{HCl}$ was added to the ash and evaporated in an oven. The residue was re-dissolved in $5 \mathrm{ml}$ of $\mathrm{HCl}$ and diluted to $25 \mathrm{ml}$ by adding de-ionized water (Brooks 1983; Van Loon 1985). The solution was analyzed for $\mathrm{Fe}, \mathrm{Mn}, \mathrm{Cu}, \mathrm{Zn}, \mathrm{Pb}$ and $\mathrm{Ni}$ by the
AAS. For the analysis of As in plant samples, $2 \mathrm{~g}$ were placed in porcelain crucibles with $20 \mathrm{ml}$ of $\mathrm{HNO}_{3}(30 \%)$, which were then heated in a water bath until completely macerated. The residue was dissolved and diluted to $25 \mathrm{ml}$ by adding de-ionized water (Fletcher 1981; Van Loon 1985). The determinations were made by HGS. For the analysis of $\mathrm{W}$ in soil/tailings and plant samples the colorimetric method was used. Dried soil samples $(0.2 \mathrm{~g})$ were placed in test tubes and were added $1 \mathrm{~g}$ of potassium bisulfate. Then the material was calcined in a muffle furnace to a maximum temperature of $570{ }^{\circ} \mathrm{C}$. Ten $\mathrm{ml}$ of $\mathrm{HCl}$ was added to the samples, which were then heated in a water bath $\left(85^{\circ} \mathrm{C}\right)$. Transferred $5 \mathrm{ml}$ of the supernatant solution to other test tubes with $5 \mathrm{ml}$ of tin chloride $\left(\mathrm{SnCl}_{2}, 20 \%\right)$ were then heated in a water bath $\left(85^{\circ} \mathrm{C}\right)$ for $10 \mathrm{~min}$. Then $1 \mathrm{ml}$ of dithiol solution was added and heated for at least $6 \mathrm{~h}$. After cooling, $5 \mathrm{ml}$ of petroleum was added and was measured the absorbance at $630 \mathrm{~nm}$ (Quin and Brooks 1972). Dried plant samples (2.0 g) were placed in porcelain crucibles, and reduced to ash in a muffle furnace over $12 \mathrm{~h}$ to a maximum temperature of $450{ }^{\circ} \mathrm{C}$. Ten $\mathrm{ml}$ of $\mathrm{SnCl}_{2}$ $(10 \%)$ was added to the ash, which were then heated in a water bath $\left(85^{\circ} \mathrm{C}\right)$ for $20 \mathrm{~min}$. Then $1 \mathrm{ml}$ of dithiol solution was added and heated for at least $6 \mathrm{~h}$. After cooling, $1 \mathrm{ml}$ of petroleum was added and was measured the absorbance at $630 \mathrm{~nm}$ (Quin and Brooks 1972).

The data quality control was performed by inserting triplicate samples into each batch. Analytical precision, defined as the percent relative variation at the $95 \%$ confidence level, ranged from 2 to $6 \%$, depending on the concentration levels. The detection limits for trace elements in soil samples were $0.025 \mathrm{mg} \mathrm{kg}^{-1}$ for As; $2.5 \mathrm{mg} \mathrm{kg}^{-1}$ for $\mathrm{Mn}, \mathrm{Cu}$ and $\mathrm{Ni} ; 5 \mathrm{mg} \mathrm{kg}^{-1}$ for $\mathrm{Fe}$ and $\mathrm{Pb} ; 0.5 \mathrm{mg} \mathrm{kg}^{-1}$ for $\mathrm{Zn}$; and $0.1 \mathrm{mg} \mathrm{kg}^{-1}$ for $\mathrm{W}$. The detection limits for trace elements in plant samples were $0.005 \mathrm{mg} \mathrm{kg}^{-1}$ for As; $1 \mathrm{mg} \mathrm{kg}^{-1}$ for $\mathrm{Fe}$; $0.5 \mathrm{mg} \mathrm{kg}^{-1}$ for $\mathrm{Mn}, \mathrm{Cu}, \mathrm{Pb}$ and $\mathrm{Ni}$; $0.1 \mathrm{mg} \mathrm{kg}^{-1}$ for $\mathrm{Zn}$; and $0.01 \mathrm{mg} \mathrm{kg}^{-1}$ for $\mathrm{W}$.

\section{Statistical testing}

We used principal components analysis (PCA) to interpret the data. A PCA is used to reduce the data dimensionality while preserving the variance-covariance structure of the data. The analysis begins with $p$ random variables $X 1$, $X 2 \ldots X p$, where no assumption of multivariate normality is required. If the principal components are derived from multivariate normal random variables, then they have a noteworthy geometric property. The axes of the constant density ellipsoids correspond to the principal components. In our study, PCA was performed using the AnDad (v. 7.10) software.

The influences of organ age and their interaction on chemical elements distribution were tested with a one-way 
analysis of variance (ANOVA) to detect significant differences between means (for $p \leq 0.05$ ). ANOVA test was performed using the SPSS statistical program (IBM SPSS Statistics 19). When the null hypothesis was rejected, ANOVA was followed by a comparison to identify which factor levels had different means. The separation of means was performed by a post hoc comparison test (LSD-test) at the $p \leq 0.05$ significance level.

\section{Results and discussion}

The results of the soil and tailings analysis are presented in Table 1 in terms of averages, contents variations and standard deviations. The basic characteristics $(\mathrm{pH}$ and organic matter) of the tested soils and tailings are presented in Table 1. In Tables 2 and 3, the averages, contents variations and standard deviations found in the analyzed samples of $P$. pinaster are presented by sampling areas and organ ages. With the aim of determining the plant-soil relationships, the BAC was determined for each element. The statistical summaries of BAC values are presented in Tables 2 and 3.

Soils and tailings in the Vale das Gatas mine area were acidic and contained a low percentage of organic matter (Table 1). The chemical data (soil/tailings and plant) were analyzed by the PCA. For the soil/tailings samples, the data matrix used in the analysis consisted of 69 samples and 10 variables $(\mathrm{pH}$, organic matter, $\mathrm{As}, \mathrm{Fe}, \mathrm{Mn}, \mathrm{Cu}, \mathrm{Zn}, \mathrm{Pb}, \mathrm{Ni}$ and $\mathrm{W})$.The first two principal components explain more than $79 \%$ of the total variance in the data (Fig. 3). The first principal component (axis 1), which explains $56.1 \%$ of the total data variance, defines a $\mathrm{pH}$-organic matter association with positive loadings and a $\mathrm{Cu}-\mathrm{Mn}-\mathrm{W}-\mathrm{As}-\mathrm{Pb}-\mathrm{Zn}$ association with negative loadings. The second component (axis 2), explaining $23.0 \%$ of the total data variance, reveals a $\mathrm{Ni}-\mathrm{Fe}$ association with positive loadings.

Thus, the data of total element concentrations mainly show two element associations. The $\mathrm{Cu}-\mathrm{Mn}-\mathrm{W}-\mathrm{As}-\mathrm{Pb}-\mathrm{Zn}$ association, which is inversely correlated with $\mathrm{pH}$ and organic matter, reflects the presence of mineralised veins in the area. The Ni-Fe association, which reveals the independent behavior that of the first group and that of the $\mathrm{pH}-$ organic matter group, maybe exists because of the similar geochemical behaviors and interdependence of these elements (i.e., in geochemical cycles, the behavior of $\mathrm{Ni}$ resemble those of $\mathrm{Fe}$ ) (Adriano 2001).

The PCA highlighted sample "populations", which are clearly distinct from one another (Fig. 4). Population A consists of samples that can be considered to have geochemical background values. This population is composed by samples from the studied areas A, B and C. Populations $\mathrm{B}$ and $\mathrm{C}$ reflect geochemical anomalies. Population $\mathrm{B}$ consist of all tailings samples and is primarily linked to a
$\mathrm{Cu}-\mathrm{Mn}-\mathrm{W}-\mathrm{As}-\mathrm{Pb}-\mathrm{Zn}$ association. Population $\mathrm{C}$, consisting of the all samples from the studied area D and one sample from area $\mathrm{A}$, is primarily associated with a $\mathrm{Ni}-\mathrm{Fe}$ association with affinities to other elements such as $\mathrm{Mn}$ and $\mathrm{Zn}$.

For the plant samples, the data matrix used in the analysis consisted of 483 samples and 8 variables (As, Fe, $\mathrm{Mn}, \mathrm{Cu}, \mathrm{Zn}, \mathrm{Pb}, \mathrm{Ni}$ and $\mathrm{W}$ ). The result of three principal axes, which explained more than $82 \%$ of the total variance, is shown in Fig. 5. Considering the retained axes and given coordinate values, the following variable associations were verified: a group composed of $\mathrm{Pb}, \mathrm{Zn}, \mathrm{W}, \mathrm{Fe}$, $\mathrm{As}, \mathrm{Cu}$ and in some way, $\mathrm{Ni}$ (axis 1); however, $\mathrm{Ni}$ is mainly explained by axis 2, as opposed to $\mathrm{Mn}$; in turn, $\mathrm{Mn}$ is best explained by axis 3 revealing an independent behavior of the $\mathrm{Pb}-\mathrm{Zn}-\mathrm{W}-\mathrm{Fe}-\mathrm{As}-\mathrm{Cu}$ association.

The PCA also highlighted plant sample "populations", which are mostly distinct from one another (Fig. 6). Population $\mathrm{A}$ is composed of all plant samples from the studied areas A, B and C. This population represents the local biogeochemical background. No significant differences between needles and stems or between tissue ages in this population were calculated. Population B results from the association of the most $\mathrm{Ni}-\mathrm{Cu}$ contaminated samples. This population is essentially composed by the 1-year-old needles and stems both on the tailings and area D. Population $\mathrm{C}$ is composed of the samples situated under the influence of the $\mathrm{Pb}-\mathrm{Zn}-\mathrm{W}-\mathrm{Fe}-\mathrm{As}$ group. This population is essentially composed by the 2- and 3-years-old needles both on the tailings and area D. Population D, consisting of the remaining samples from tailings and area D (2-, 3- and 4-years-old stems), seems to establish the transition between the $\mathrm{B}$ and $\mathrm{C}$ populations.

The content variations in vegetal materials were, in general, strongly related to the content variations in soils. It has also been verified that in contaminated locations or tailings, the concentration of metals in plant tissues is high due to the high metal concentrations in the soil. The maritime pine trees growing in the tailings and in the contaminated soils (area D) accumulated the various researched chemical elements in quantities greater than those verified in the plants of the representative areas of the local geochemical background (areas A, B, C), and than those that are typically observed in this species. The observed values also allowed us to verify that the contents of several elements in the vegetal material depend as much on the plant organ as on its age (Fig. 7a, b). In the contaminated sampling locations (tailings and area D), the older needles (2- and 3-years-old) show a tendency to accumulate higher concentrations of $\mathrm{As}, \mathrm{Fe}, \mathrm{Zn}, \mathrm{Pb}$ and $\mathrm{W}$. While the $\mathrm{Ni}$ and $\mathrm{Cu}$ were preferentially accumulated in young needles and stems (1-year-old). This was confirmed by PCA analysis (Fig. 6) and ANOVA analysis (Table 4). In Table 5, the result of post hoc comparison test 
Table 1 Statistical summaries of $\mathrm{pH}$, organic matter and total concentrations of studied elements in soils and tailings samples

\begin{tabular}{|c|c|c|c|c|c|}
\hline Parameter & $\begin{array}{l}\text { Sampling } \\
\text { area }\end{array}$ & Mean & Minimum & Maximum & $\begin{array}{l}\text { Standard } \\
\text { deviation }\end{array}$ \\
\hline \multirow[t]{5}{*}{$\mathrm{pH}$} & Tailings & 3.7 & 3.5 & 4.2 & 0.35 \\
\hline & Area A & 5.9 & 5.6 & 6.3 & 0.36 \\
\hline & Area B & 5.5 & 5.2 & 6.1 & 0.44 \\
\hline & Area $\mathrm{C}$ & 4.9 & 4.5 & 5.2 & 0.31 \\
\hline & Area D & 4.9 & 4.7 & 5.1 & 0.28 \\
\hline \multirow{5}{*}{$\begin{array}{l}\text { Organic } \\
\text { matter (\%) }\end{array}$} & Tailings & 0.30 & 0.26 & 0.36 & 0.05 \\
\hline & Area A & 2.52 & 0.31 & 3.88 & 1.93 \\
\hline & Area B & 4.65 & 3.13 & 6.10 & 1.51 \\
\hline & Area $\mathrm{C}$ & 4.35 & 3.31 & 6.31 & 1.34 \\
\hline & Area D & 1.90 & 0.49 & 3.31 & 1.99 \\
\hline \multirow[t]{5}{*}{ As $\left(\mathrm{mg} \mathrm{kg}^{-1}\right)$} & Tailings & 1,963 & 541 & 5,770 & 2,175 \\
\hline & Area A & 37.7 & 26.7 & 48.1 & 10.1 \\
\hline & Area B & 47.8 & 37.4 & 66.8 & 16.5 \\
\hline & Area $\mathrm{C}$ & 56.7 & 45.5 & 69.1 & 11.8 \\
\hline & Area D & 128 & 122 & 134 & 8.39 \\
\hline \multirow[t]{5}{*}{$\mathrm{Fe}\left(\mathrm{mg} \mathrm{kg}^{-1}\right)$} & Tailings & 36,483 & 28,600 & 46,859 & 6,689 \\
\hline & Area A & 32,816 & 20,531 & 60,100 & 18,613 \\
\hline & Area B & 24,355 & 22,267 & 26,077 & 2,049 \\
\hline & Area C & 22,684 & 18,482 & 30,350 & 6,720 \\
\hline & Area D & 49,298 & 44,618 & 53,975 & 6,608 \\
\hline \multirow[t]{5}{*}{$\operatorname{Mn}\left(\mathrm{mg} \mathrm{kg}^{-1}\right)$} & Tailings & 667 & 406 & 898 & 208 \\
\hline & Area A & 243 & 132 & 565 & 214 \\
\hline & Area B & 139 & 119 & 167 & 25.6 \\
\hline & Area $\mathrm{C}$ & 120 & 103 & 146 & 22.6 \\
\hline & Area D & 507 & 457 & 558 & 71.2 \\
\hline \multirow[t]{5}{*}{$\mathrm{Cu}\left(\mathrm{mg} \mathrm{kg}^{-1}\right)$} & Tailings & 259 & 164 & 352 & 75.2 \\
\hline & Area A & 24.5 & 11.7 & 31.0 & 8.78 \\
\hline & Area B & 24.4 & 23.0 & 26.7 & 2.01 \\
\hline & Area C & 20.8 & 12.0 & 29.0 & 8.52 \\
\hline & Area D & 112 & 40.0 & 184 & 102 \\
\hline \multirow[t]{5}{*}{$\mathrm{Zn}\left(\mathrm{mg} \mathrm{kg}^{-1}\right)$} & Tailings & 302 & 187 & 469 & 103 \\
\hline & Area A & 123 & 107 & 134 & 11.3 \\
\hline & Area B & 119 & 73.3 & 159 & 43.2 \\
\hline & Area $\mathrm{C}$ & 85.8 & 63.1 & 98.1 & 19.7 \\
\hline & Area D & 275 & 117 & 433 & 224 \\
\hline \multirow[t]{5}{*}{$\mathrm{Pb}\left(\mathrm{mg} \mathrm{kg}^{-1}\right)$} & Tailings & 2,152 & 584 & 6,299 & 2,372 \\
\hline & Area A & 85.5 & 63.0 & 102 & 19.6 \\
\hline & Area B & 84.4 & 63.3 & 103 & 19.9 \\
\hline & Area $\mathrm{C}$ & 66.1 & 55.4 & 78.0 & 11.3 \\
\hline & Area D & 110 & 105 & 115 & 7.29 \\
\hline \multirow[t]{5}{*}{$\mathrm{Ni}\left(\mathrm{mg} \mathrm{kg}^{-1}\right)$} & Tailings & 21.1 & 11.6 & 30.8 & 6.94 \\
\hline & Area A & 32.1 & 18.2 & 61.2 & 19.9 \\
\hline & Area B & 23.6 & 23.1 & 24.5 & 0.74 \\
\hline & Area C & 22.4 & 17.8 & 29.0 & 5.88 \\
\hline & Area D & 54.4 & 49.8 & 59.0 & 6.50 \\
\hline \multirow[t]{5}{*}{$\mathrm{W}\left(\mathrm{mg} \mathrm{kg}^{-1}\right)$} & Tailings & 287 & 11.0 & 636 & 290 \\
\hline & Area A & 9.83 & 5.00 & 12.0 & 3.28 \\
\hline & Area B & 4.57 & 2.00 & 7.09 & 2.55 \\
\hline & Area $\mathrm{C}$ & 4.07 & 3.20 & 5.10 & 0.96 \\
\hline & Area D & 62.4 & 59.2 & 65.6 & 4.48 \\
\hline
\end{tabular}

(LSD-test) for separation of means of the different ages of needles and stems is reported: the different letters close to the means indicate which ones are significantly different, according to the comparison test. Therefore, there were some significant differences in accumulation of chemical elements depending on the age and type of biological tissue.

Arsenic is not essential for vegetal metabolism, and is highly toxic to plants with a toxicity level of approximately $2 \mathrm{mg} \mathrm{kg}^{-1}$ (Kabata-Pendias 2010). Given this toxicity level, the concentrations observed may be considered high (Tables 2 and 3 ). The observed values allowed us to verify that the greatest concentrations of As were present in the foliar material, both in the soils, representative of the geochemical background, and in the tailings and contaminated soils. The concentration of this element always increases with the age of the needle, though not as drastically in plants that are not subjected to strong contamination (Fig. 7a). This relationship is more significant when the soils are contaminated by As. In contrast, the concentrations of As in the stems decreased with age (Fig. 7b). This behavior might be related to a plant defense mechanism against high concentrations of this toxic element, which is the translocation of As to the older needles that eventually fall from the plant.

Considering to the plant/soil relations and Perelman's classification, it was verified that all of the woody material and the youngest foliar material were characterized by BAC values (Tables 2 and 3) indicating very weak to weak absorption of As, while the older foliar material (3-years-old) had BAC values indicative of very weak and intermediate absorption with the particular trait that the lowest plant/soil ratios (very weak absorption) were found in the most contaminated area (tailings). Thus, in this species, there is a limiting behavior for very high concentrations of As in the substrate or in the influence of a factor related to soil conditions such as the $\mathrm{pH}$ or the presence of $\mathrm{Mn}$ and Fe oxides, which have been reported to limit As bioavailability. The bioavailability of As and metals can be affected mainly by the three following factors (e.g., Adriano 2001; Mani et al. 2012): (1) soil capacity $(\mathrm{pH}$, cation exchange capacity, organic matter, amount and type of clay, ion interactions, amount of $\mathrm{Fe}$ and $\mathrm{Mn}$ oxides and redox potential); (2) plant capacity, which depends on the species, cultivar and age of plant part; and (3) the plant-trace element interactions.

The concentration of $\mathrm{Fe}$ in $P$. pinaster needles increased progressively with the age of the organ (Fig. 7a, b). Kabata-Pendias (2010) reported that Dolobovskaya also observed Fe retention by the oldest needles in exemplars of Pinus sibirica Turcz (Siberia pine tree) and $P$. pinaster, respectively. The use and retention of $\mathrm{Fe}$ in the needles do 


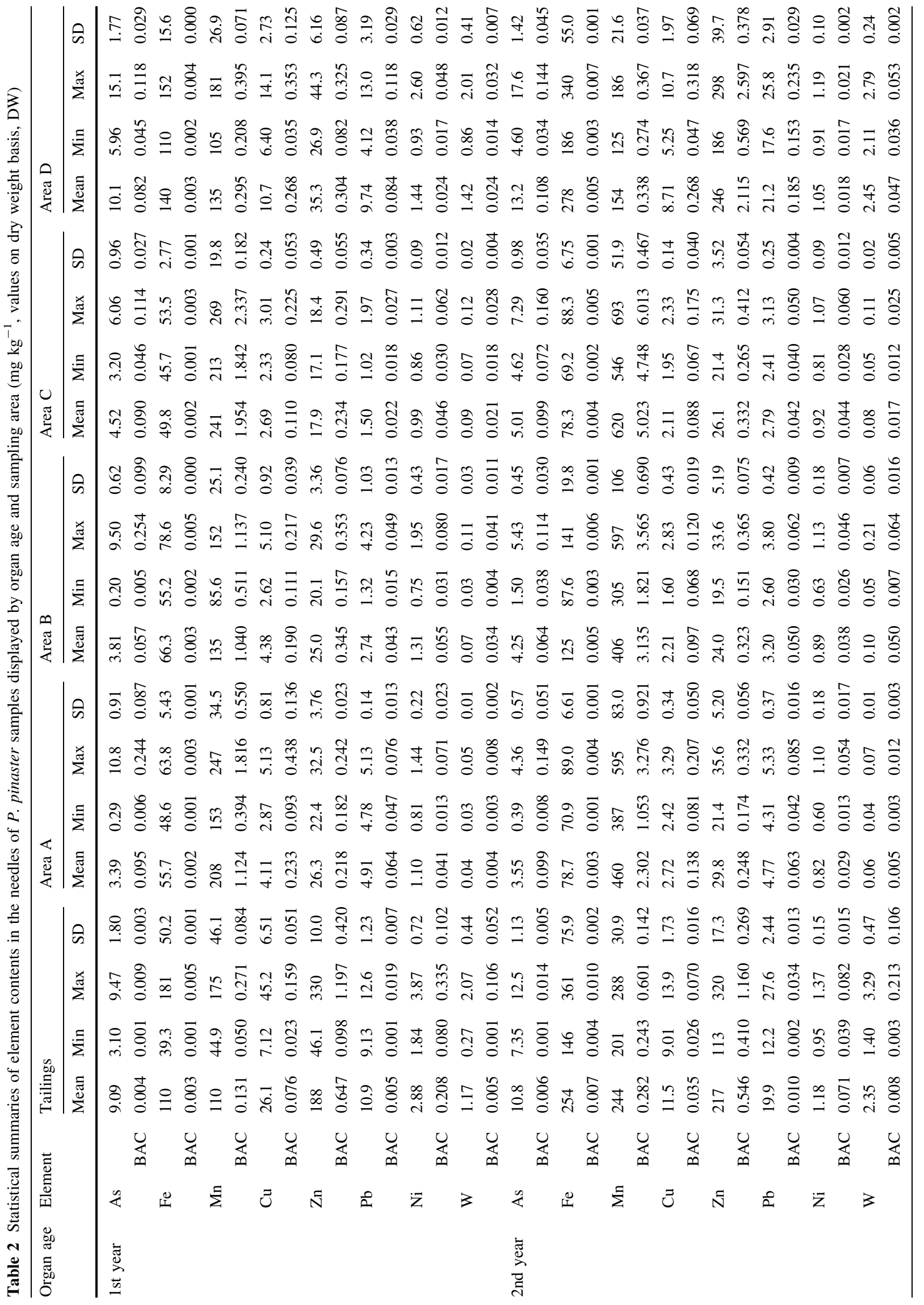




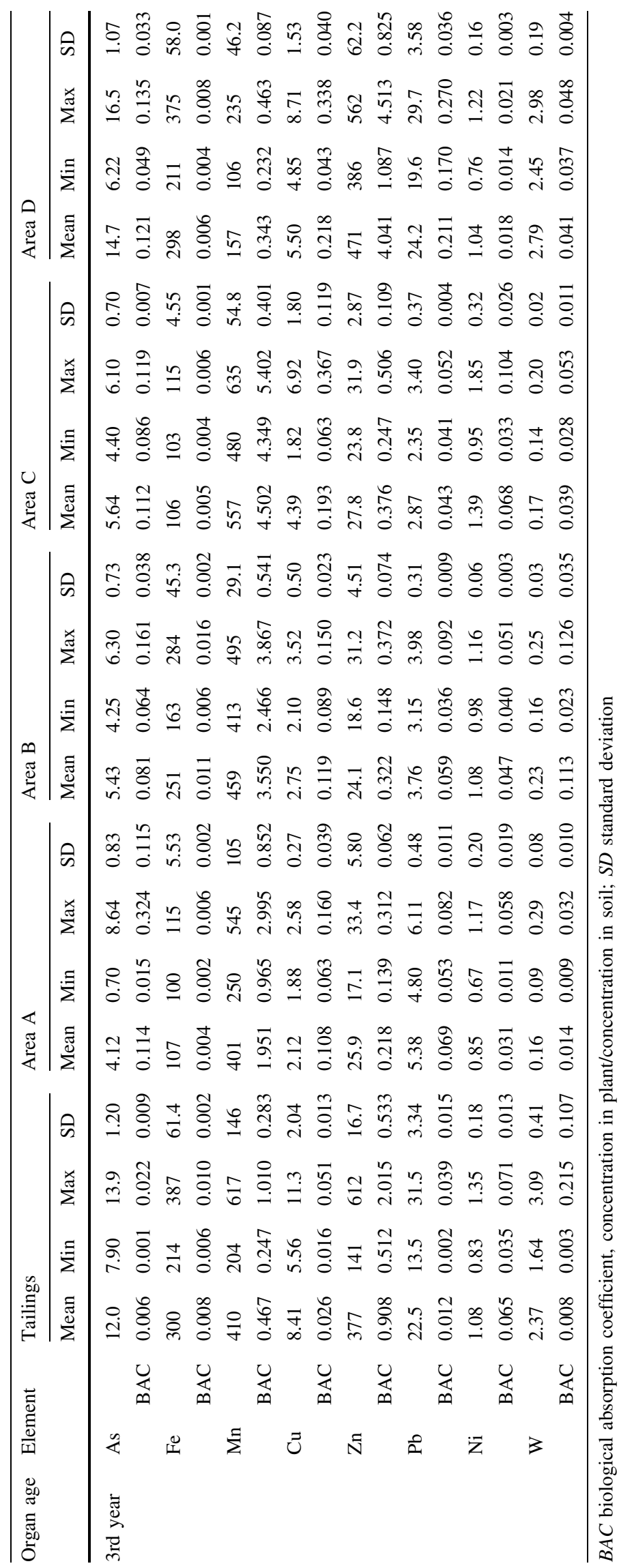




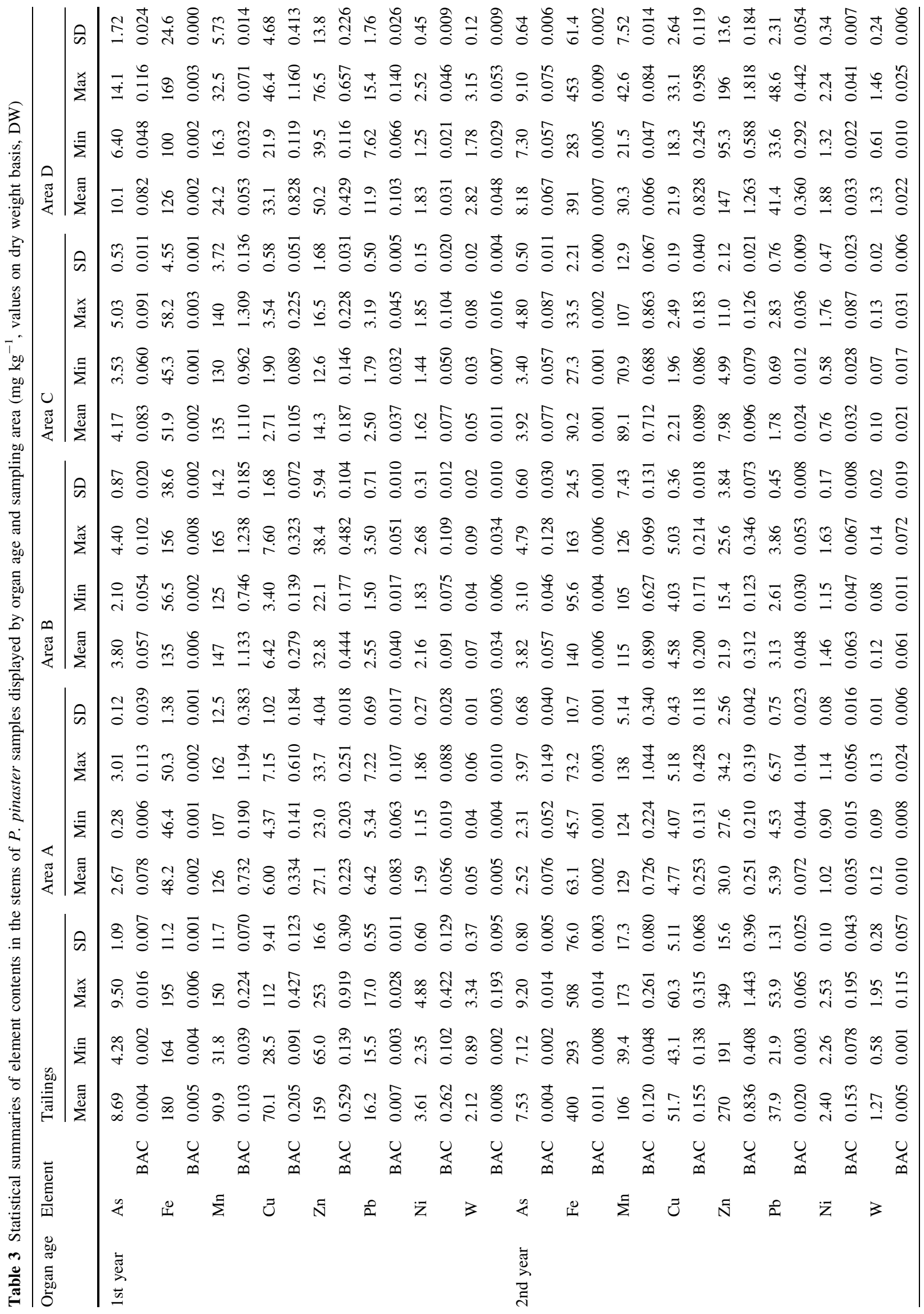




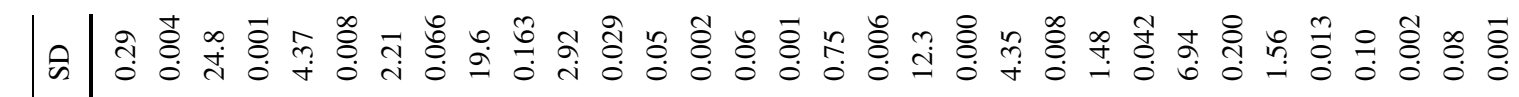
毛

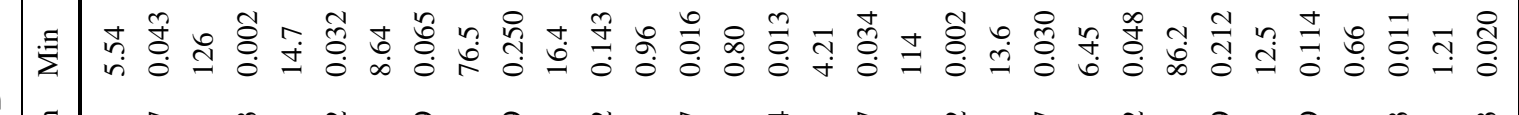
尊

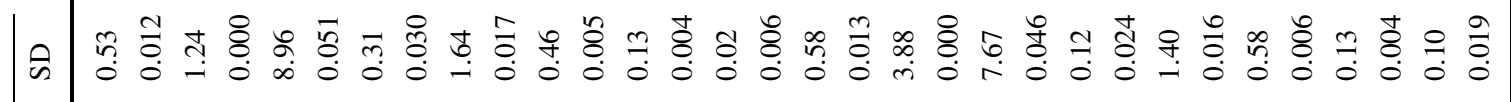

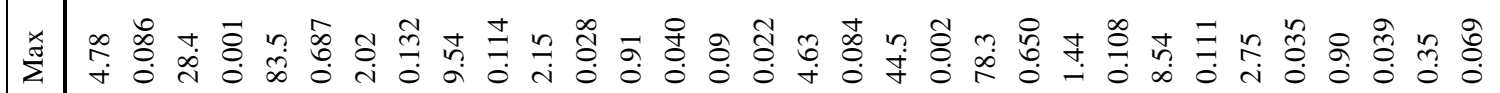

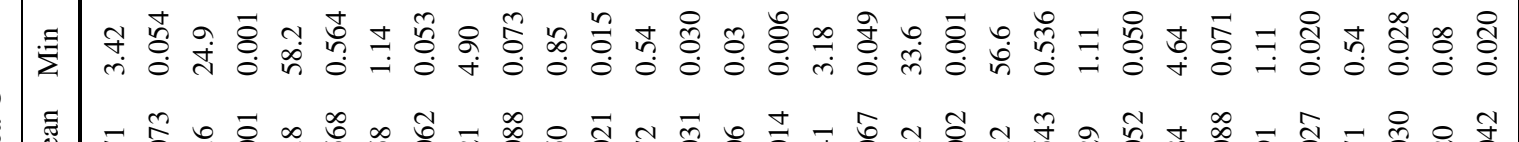
苞

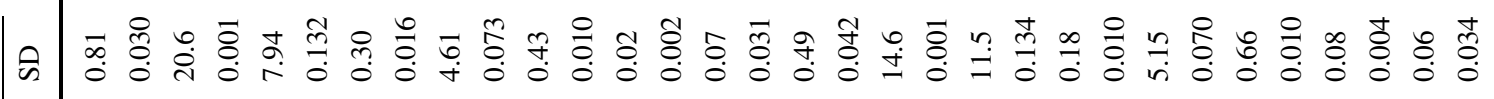

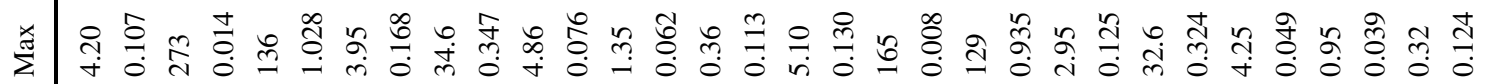

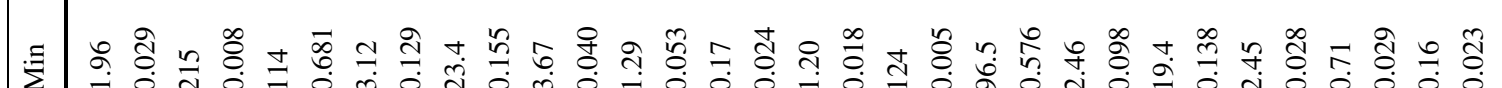

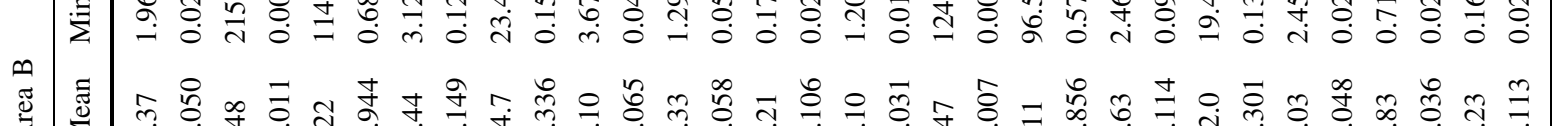

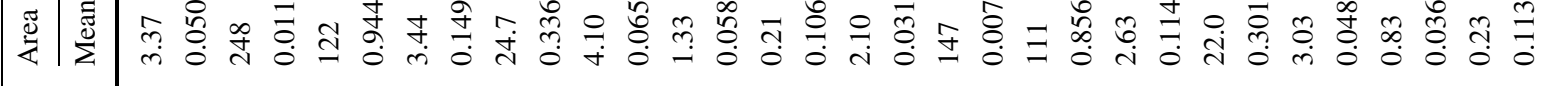
|

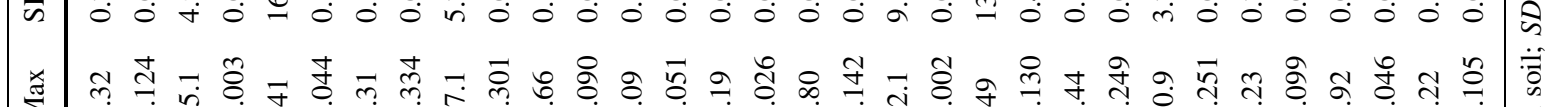

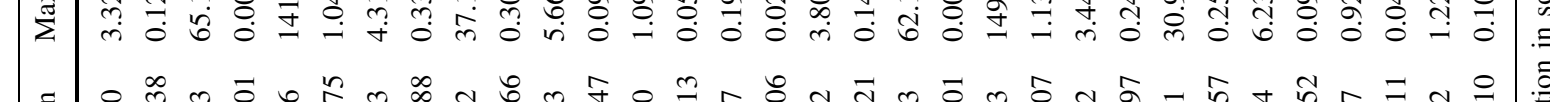

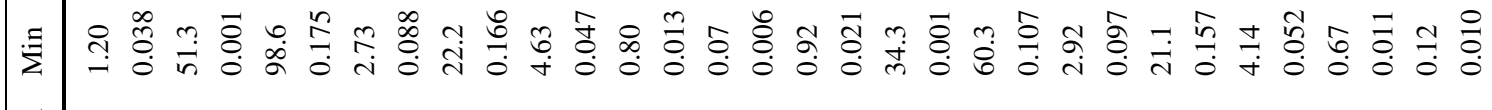

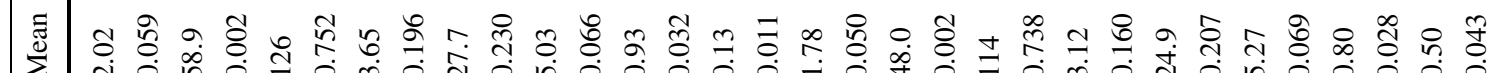

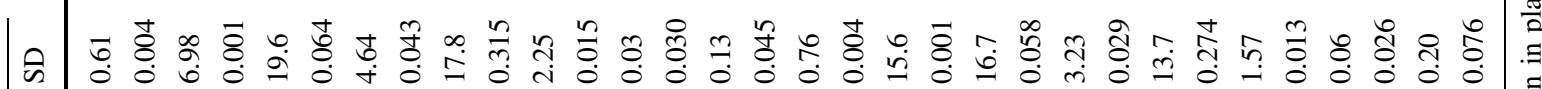

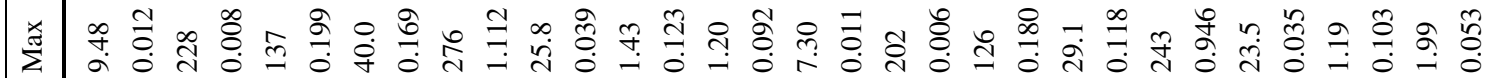

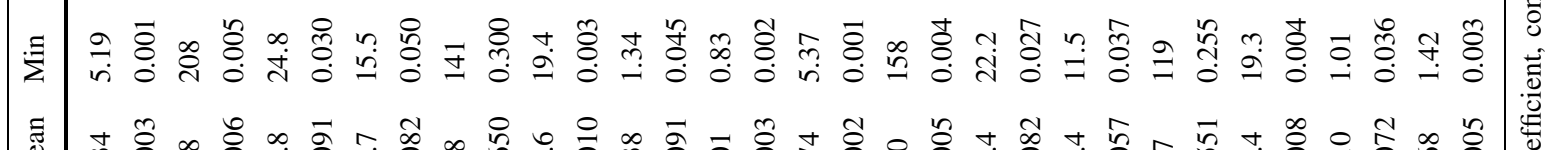

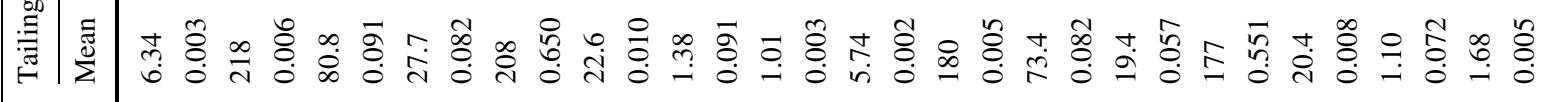

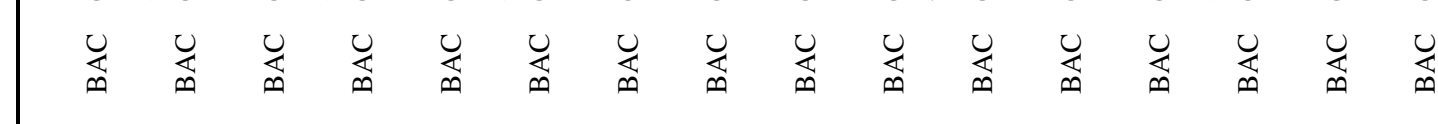

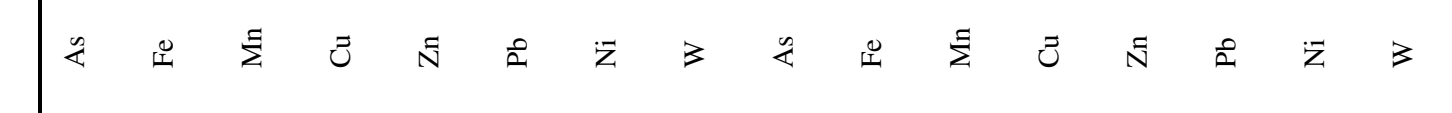
苂 


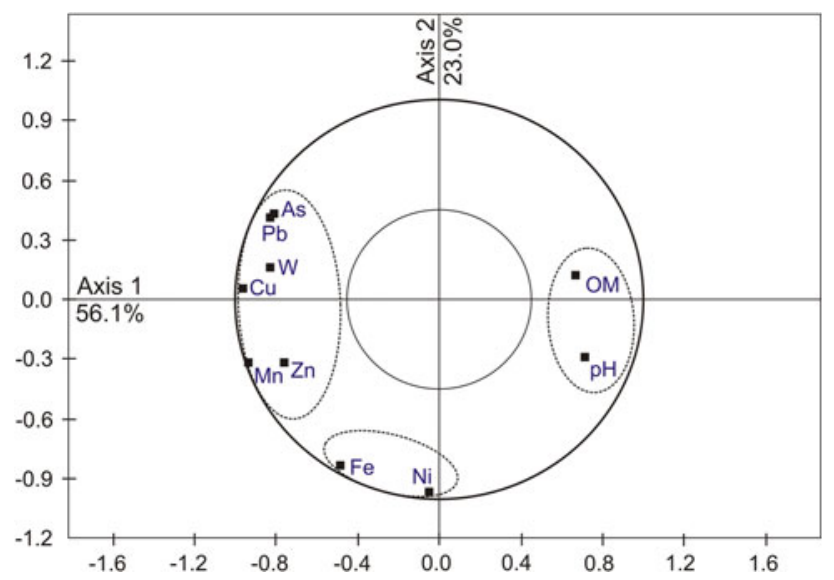

Fig. 3 Projection of the variables in the first factorial plan of the principal components analysis (PCA) (soil/tailings samples)

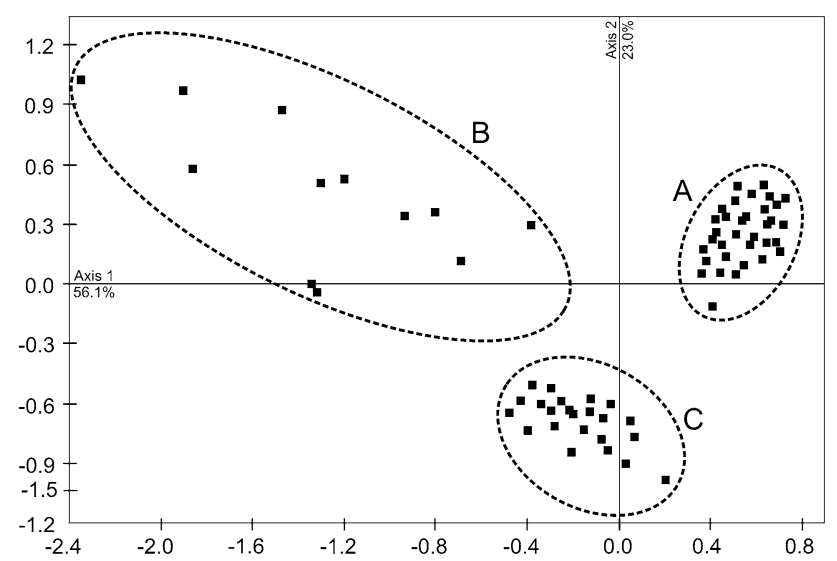

Fig. 4 Projection of the samples in the first factorial plan of the principal components analysis (PCA) (soil/tailings samples)

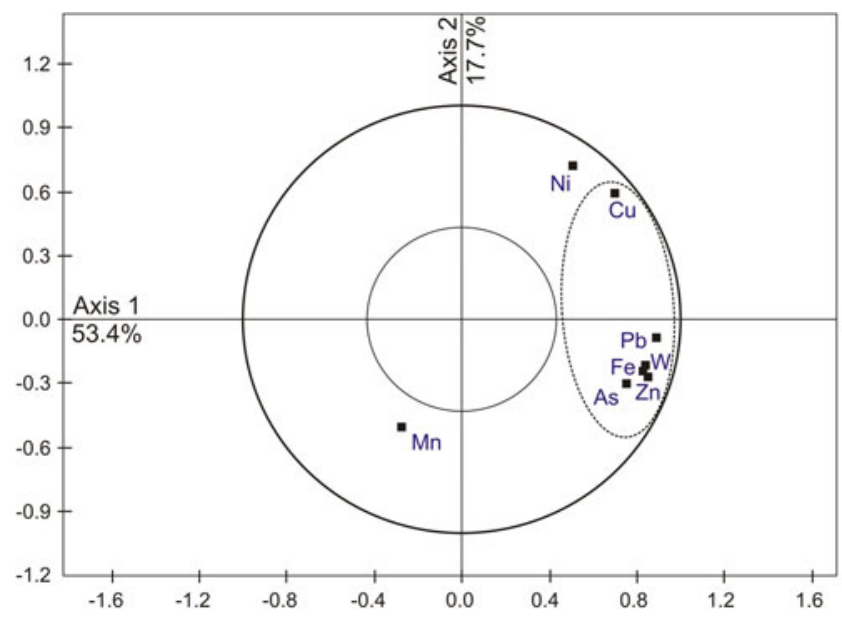

not seem to be controlled by factors inherent to the level of contamination, given that the retention behaviors were similar in the different sampling areas. Meanwhile, in the woody parts, it seems to be interference from those factors in the bioutilization of this element. Thus, it was verified that the stems of the plants that grew in the tailings and in the contaminated area exhibit a high level of retention of this element in the tissues with 2-years-old, manifesting, from then on, a behavior close to that of the plants growing in the soils, representative of the geochemical background. For Fe, we observed very low plant/soil ratios (Tables 2 and 3), revealing weak to very weak absorption, despite the fact that $\mathrm{Fe}$ is an essential nutrient. This behavior, however, seems to be common in soils that are very rich in $\mathrm{Fe}$, and where the geochemical forms are very poorly soluble making the availability of the element very low.

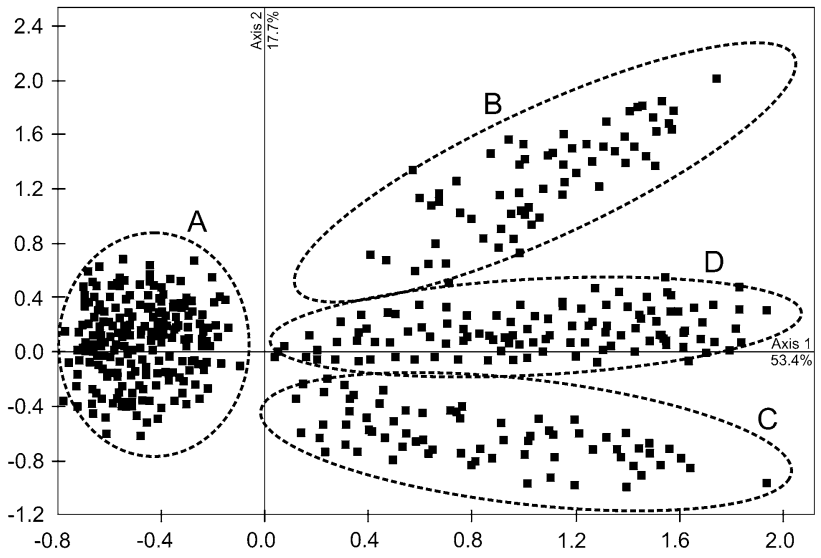

Fig. 6 Projection of the samples in the first factorial plan of the principal components analysis (PCA) (plant samples)

Fig. 5 Projection of the variables in the two first factorial plans of the principal components analysis (PCA) (plant samples)

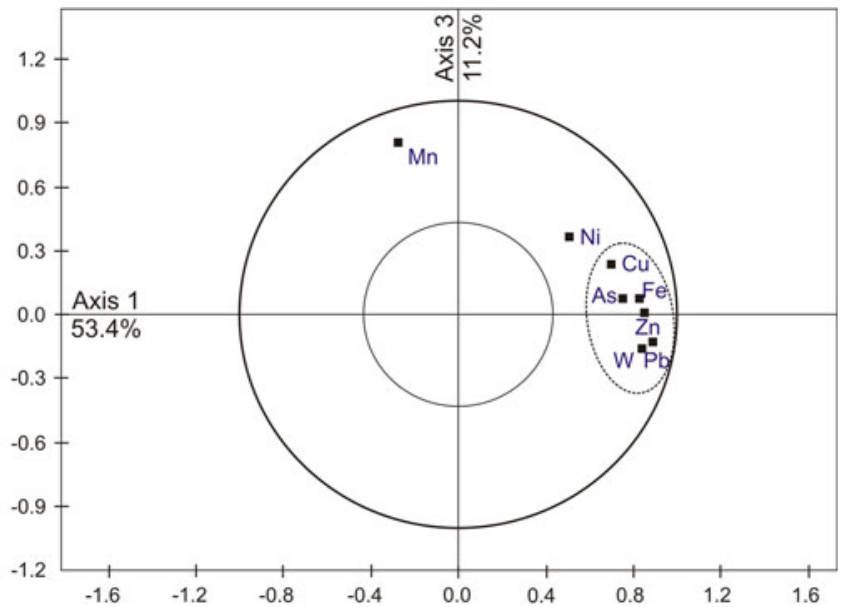



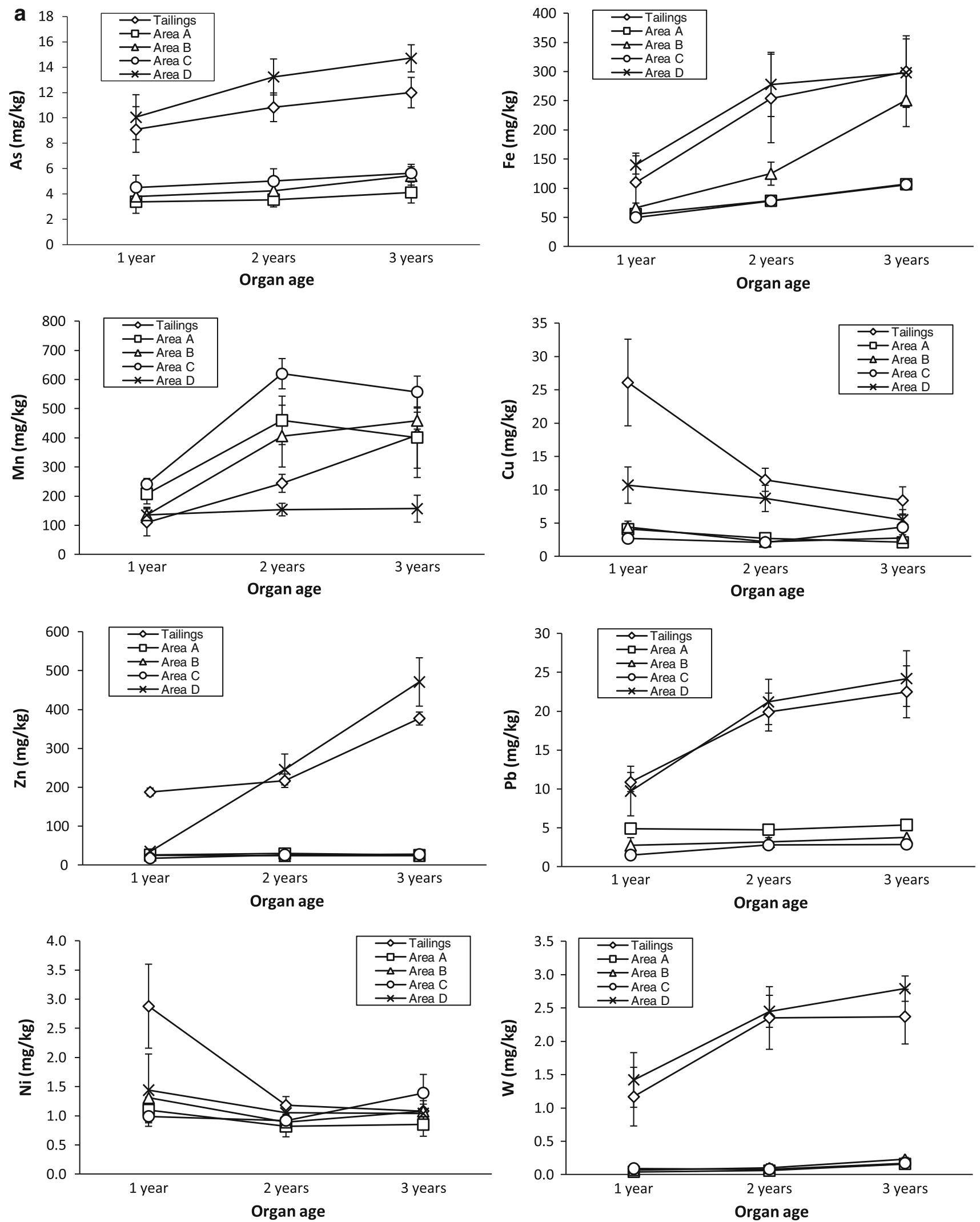

Fig. 7 a Variations in the levels of $\mathrm{As}, \mathrm{Fe}, \mathrm{Mn}, \mathrm{Cu}, \mathrm{Zn}, \mathrm{Pb}, \mathrm{Ni}$ and $\mathrm{W}$ in the needles of $P$. pinaster samples considering the organ age and the sampling area (mean $\pm \mathrm{SD}$ ). b Variations in the levels of As, Fe,

$\mathrm{Mn}, \mathrm{Cu}, \mathrm{Zn}, \mathrm{Pb}, \mathrm{Ni}$ and $\mathrm{W}$ in the stems of $P$. pinaster samples considering the organ age and the sampling area (mean \pm SD) 

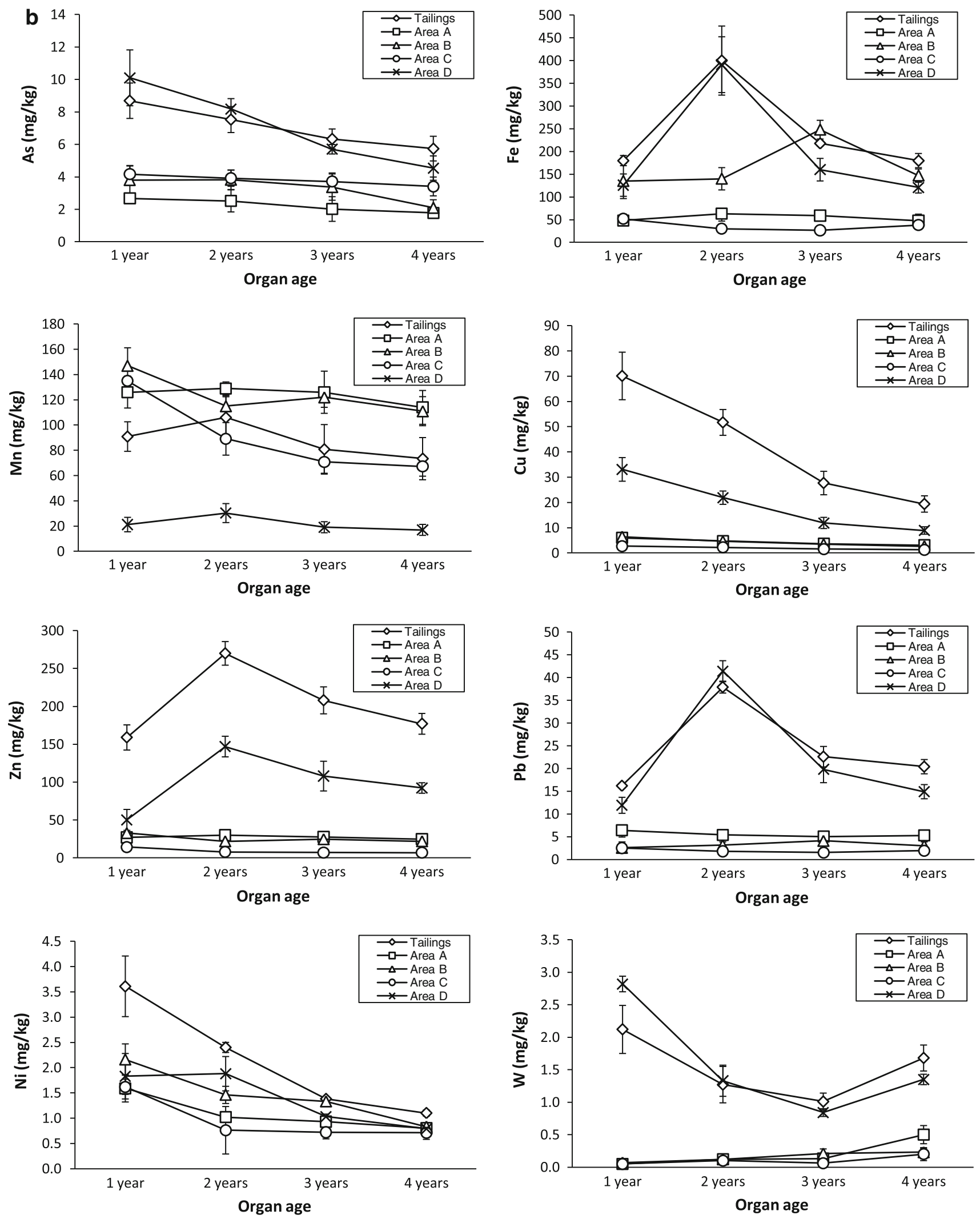

Fig. 7 continued 
Table 4 Result of statistical analysis of variance (ANOVA), for test the influences of organ age on chemical elements concentration

\begin{tabular}{|c|c|c|c|c|c|c|c|c|c|}
\hline $\begin{array}{l}\text { Plant } \\
\text { organ }\end{array}$ & Variables & $\begin{array}{l}\text { Sum of squares } \\
\text { between groups }\end{array}$ & $d f$ & $\begin{array}{l}\text { Mean square } \\
\text { between groups }\end{array}$ & $\begin{array}{l}\text { Sum of squares } \\
\text { within groups }\end{array}$ & $d f$ & $\begin{array}{l}\text { Mean square } \\
\text { within groups }\end{array}$ & $F$ & $\begin{array}{l}\text { Significant } \\
\text { level }\end{array}$ \\
\hline \multirow[t]{8}{*}{ Needles } & As & 174.68 & 2 & 87.34 & 3103.05 & 204 & 15.21 & 5.74 & $0.004 *$ \\
\hline & $\mathrm{Fe}$ & 568706.63 & 2 & 284353.31 & 1360522.59 & 204 & 6669.23 & 42.64 & $0.000 *$ \\
\hline & $\mathrm{Mn}$ & 2422058.05 & 2 & 1211029.02 & 3883559.74 & 204 & 19037.06 & 63.61 & $0.000 *$ \\
\hline & $\mathrm{Cu}$ & 888.71 & 2 & 444.35 & 9177.09 & 204 & 44.99 & 9.88 & $0.000^{*}$ \\
\hline & $\mathrm{Zn}$ & 535542.47 & 2 & 267771.23 & 4268173.74 & 204 & 20922.42 & 12.80 & $0.000 *$ \\
\hline & $\mathrm{Pb}$ & 1300.32 & 2 & 650.16 & 13441.62 & 204 & 65.89 & 9.87 & $0.000 *$ \\
\hline & $\mathrm{Ni}$ & 14.28 & 2 & 7.137 & 53.32 & 204 & 0.26 & 27.31 & $0.000 *$ \\
\hline & W & 12.23 & 2 & 6.11 & 224.16 & 204 & 1.10 & 5.563 & $0.004 *$ \\
\hline \multirow[t]{8}{*}{ Stems } & As & 129.76 & 3 & 43.25 & 1504.32 & 272 & 5.53 & 7.82 & $0.000^{*}$ \\
\hline & $\mathrm{Fe}$ & 410778.41 & 3 & 136926.14 & 2817127.95 & 272 & 10357.09 & 13.22 & $0.000^{*}$ \\
\hline & $\mathrm{Mn}$ & 29923.97 & 3 & 9974.66 & 507668.62 & 272 & 1866.43 & 5.34 & $0.001 *$ \\
\hline & $\mathrm{Cu}$ & 11023.01 & 3 & 3674.34 & 94888.77 & 272 & 348.86 & 10.53 & $0.000 *$ \\
\hline & $\mathrm{Zn}$ & 56882.56 & 3 & 18960.85 & 1751212.58 & 272 & 6438.28 & 2.95 & $0.033^{*}$ \\
\hline & $\mathrm{Pb}$ & 3973.57 & 3 & 1324.52 & 35296.78 & 272 & 129.77 & 10.21 & $0.000^{*}$ \\
\hline & $\mathrm{Ni}$ & 70.68 & 3 & 23.559 & 84.65 & 272 & 0.31 & 75.70 & $0.000 *$ \\
\hline & W & 10.93 & 3 & 3.64 & 165.87 & 272 & 0.61 & 5.98 & $0.001 *$ \\
\hline
\end{tabular}

* Significant difference between the samples $(p \leq 0.05)$

Table 5 Result of post hoc comparison test (LSD-test), for separation of means of the different ages of needles and stems

\begin{tabular}{llrccl}
\hline Plant organ & Variables & $\begin{array}{c}\text { 1-year-old } \\
(n=69)\end{array}$ & $\begin{array}{l}\text { 2-years-old } \\
(n=69)\end{array}$ & $\begin{array}{c}\text { 3-years-old } \\
(n=69)\end{array}$ & $\begin{array}{l}\text { 4-years-old } \\
(n=69)\end{array}$ \\
\hline \multirow{2}{*}{ Needles } & $\mathrm{As}$ & $5.68 \mathrm{~A}$ & $6.21 \mathrm{~A}$ & $7.84 \mathrm{~B}$ & - \\
& $\mathrm{Fe}$ & $82.45 \mathrm{~A}$ & $160.20 \mathrm{~B}$ & $209.81 \mathrm{C}$ & - \\
& $\mathrm{Mn}$ & $164.15 \mathrm{~A}$ & $384.45 \mathrm{~B}$ & $401.80 \mathrm{~B}$ & - \\
& $\mathrm{Cu}$ & $9.40 \mathrm{~A}$ & $5.34 \mathrm{~B}$ & $4.74 \mathrm{~B}$ & - \\
& $\mathrm{Zn}$ & $58.85 \mathrm{~A}$ & $107.28 \mathrm{~A}$ & $182.48 \mathrm{~B}$ & - \\
& $\mathrm{Pb}$ & $10.31 \mathrm{~B}$ & $11.65 \mathrm{~B}$ & - \\
& $\mathrm{Ni}$ & $0.97 \mathrm{~B}$ & $1.08 \mathrm{~B}$ & - \\
& $\mathrm{W}$ & $0.55 \mathrm{~A}$ & $0.99 \mathrm{~B}$ & $1.11 \mathrm{~B}$ & - \\
& $\mathrm{As}$ & $5.49 \mathrm{~A}$ & $4.30 \mathrm{~A}$ & $4.37 \mathrm{~B}$ & $3.81 \mathrm{~B}$ \\
& $\mathrm{Fe}$ & $105.55 \mathrm{~A}$ & $200.82 \mathrm{~B}$ & $142.28 \mathrm{C}$ & $107.37 \mathrm{~A}$ \\
& $\mathrm{Mn}$ & $105.43 \mathrm{~A}$ & $95.16 \mathrm{AB}$ & $85.14 \mathrm{BC}$ & $77.81 \mathrm{C}$ \\
& $\mathrm{Cu}$ & $23.28 \mathrm{~A}$ & $17.34 \mathrm{~A}$ & $9.99 \mathrm{~B}$ & $7.13 \mathrm{~B}$ \\
& $\mathrm{Zn}$ & $76.93 \mathrm{~A}$ & $95.26 \mathrm{~B}$ & $76.37 \mathrm{AB}$ & $65.24 \mathrm{~A}$ \\
& $\mathrm{~Pb}$ & $2.18 \mathrm{~A}$ & $17.67 \mathrm{~B}$ & $10.60 \mathrm{~A}$ & $9.09 \mathrm{~A}$ \\
& $\mathrm{Ni}$ & $0.96 \mathrm{~A}$ & $0.55 \mathrm{BC}$ & $0.45 \mathrm{~B}$ & $0.79 \mathrm{AC}$ \\
\hline
\end{tabular}

The letters A, B, C and D

characterize the mean differences. The means significantly different from the others $(p \leq 0.05)$ are indicated with a different letter. The two paired letters refer to similitude with more a two groups
The variation in the contents of Mn revealed identical behaviors in the different sampling areas; therefore, the utilization and retention of this element, both in the needles and in the stems, seem to be indifferent to the factors inherent to the contamination. Meanwhile, the plants that grew on the tailings showed a low percentage of retained $\mathrm{Mn}$ in growing needles. This fact might be related to several factors, namely the occurrence of $\mathrm{Mn}$ in forms that render its difficulty for absorption through the roots (immobile oxides) and a high rate of bioutilization of the quantities absorbed, given that the $\mathrm{Mn}$ is a micronutrient essential for photosynthesis and necessary in chlorophyll synthesis (Nagaraju and Karimulla 2002; Silva and Williams 2001). The needles always showed strong to intense absorption of $\mathrm{Mn}$, and the stems had BAC values indicative of intermediate to strong absorption in almost all of the samples (Tables 2 and 3). This result can also help to explain the low ratios for Fe because according to Nagaraju and Karimulla (2001), when Mn is present in the soil in medium to high concentrations, it can induce deficiencies 
in Fe in plants as the result of competition in the absorption and translocation of these elements.

The concentrations of $\mathrm{Cu}$ were higher in the younger material, both foliar and woody, with the woody material showing a less marked variation over time. In contrast, in the needles, the concentration was visibly higher in newly formed needles than in the older needles (Fig. 7a, b). This behavior was identical in the different areas mentioned and is likely inherent to vegetal metabolism, corresponding to what was documented by Dolobovskaya for $P$. sibirica (Kabata-Pendias 2010). The samples of different organs and ages had BAC values that indicated weak to intermediate absorption of $\mathrm{Cu}$ (Tables 2 and 3). We also verified for all of the exemplars that, in the tailings, although the content of $\mathrm{Cu}$ in the substrate was high, the $\mathrm{Cu}$ content in the plant was not. This result may be related to the reduced bioavailability of $\mathrm{Cu}$ in these soils, reflecting the ability of $\mathrm{Cu}$ to be adsorbed and co-precipitated with oxy-hydroxides of Fe, Mn and Al (Adriano 2001).

For $\mathrm{Zn}$, we verified behavior differences according to the sampling area. We observed similar patterns in the plants from the tailings and area D (Fig. 7a, b), verifying that in the needles the concentration of $\mathrm{Zn}$ increases with age, while in the stems the concentration increases in the second year and then decreases with age. The behavior in these two areas might reflect the performance of physiological mechanisms attempting to re-establish balance in response to disturbances caused by the presence of toxic elements in excessive quantities. The BAC results allowed us to verify that the absorption of $\mathrm{Zn}$ can be classified as intermediate for all of the samples, which had high BAC values, especially the exemplars growing in the tailings (Table 2 and 3). This fact should reflect, on one hand, the high quantities of this element existing in the substrate (Table 1), and on the other hand, the easy utilization of this element by the plants, given that $\mathrm{Zn}$ is an element endowed with great mobility in soils with low contents of organic matter (Kabata-Pendias 2010). However, the highest BAC values (strong absorption) were observed in area D, in 2- and 3-years-old needles and in 2-years-old stems.

The variation in the content of $\mathrm{Pb}$ also demonstrates some differences in behavior between plants outside and inside the contaminated area. In the plants that grew in the tailings and in area D (Fig. 7a, b), the concentrations of $\mathrm{Pb}$ in the needles were shown to increase with age, whereas the stems showed an increase in the concentrations of this metal in the second year and then a decrease with age. For $\mathrm{Pb}$, the values of BAC (Tables 2 and 3) indicated, for all organs and ages, very weak to weak absorption. However, it is necessary to bear in mind that, in this study, only the aerial parts of the plant were sampled, given that there is a general consensus that $\mathrm{Pb}$ is mainly accumulated in the roots and is barely translocated to the other parts of the plant. The exception was the exemplars grown in the contaminated area, for which the BAC values indicated intermediate absorption values.

The variation in the content of $\mathrm{Ni}$ was identical to that for $\mathrm{Cu}$, especially in the tailings (Fig. 7a, b) with a decrease with age in the needles and the stems. Thus, in the plants that grow in highly contaminated soils, the translocation of $\mathrm{Ni}$ appears to be inhibited, with possible accumulation in the cellular vacuoles, perhaps due to the antagonism between $\mathrm{Ni}$ and other trace elements that are present in excess in the plants. For $\mathrm{Ni}$, the BAC values indicate weak to intermediate absorption.

The variations in the contents of $\mathrm{W}$ showed differences in behavior between areas outside and inside the contaminated area (Fig. 7a, b). In the areas representative of the geochemical background, the concentrations of $\mathrm{W}$ increased with the age, both in the foliar and in the woody material. In contrast, in the tailings and in the contaminated soils, it was verified that there was an increase in the concentration of this metal in woody material with 1-year-old, and a significant decrease after the first year of age with an increase being observed again in the oldest material (4-years-old). The W contents were higher in older needles (2- and 3-years-old). The BAC values for $\mathrm{W}$ revealed very weak to weak absorption for all areas.

Those specimens of $P$. pinaster growing in tailings and contaminated soils shows tolerance to imposed stress conditions (metal-contamination and nutrient deficiency) and can fulfill the objectives of stabilization, pollution attenuation and visual improvement. Besides, this species is drought-resistant and has high biomass and bioproductivity. In fact, the constraints related to plant establishment and amendment of the physical-chemical properties of the metalliferous soils depends upon the choice of appropriate plant species. Therefore, the plant community tolerant to toxic trace elements play a major role in remediation of degraded mine soils. Thus, for the Vale das Gatas mine area, this type of approach requires more information about plant communities growing on these soils and tailings to assess their potential for mine restoration and minimization of mining impacts.

\section{Conclusion}

The values obtained allowed us to conclude that the content of chemical elements of the needles and stems of maritime pine tree $(P$. pinaster) depend as much on the plant organ as on the age, especially in the most contaminated locations. Thus, in sampling campaigns for biogeochemical studies, it is important to consider both the organ and the age of the sample. Therefore, it is not convenient to use a mix of foliar and woody material in the same 
biogeochemical sample. The age of the organ is also important, because for the researched elements (As, Fe, $\mathrm{Mn}, \mathrm{Cu}, \mathrm{Zn}, \mathrm{Pb}, \mathrm{Ni}, \mathrm{W}$ ) this species showed a great variability in the accumulation behavior with age. For each particular element that was studied, there is a plant organ and an age that may be more suited for sampling to reflect higher bioaccumulated concentrations. Thus, the 1-year-old needles and stems accumulated higher levels of $\mathrm{Ni}$ and $\mathrm{Cu}$. While the older needles accumulated higher levels of As, $\mathrm{Fe}, \mathrm{Zn}, \mathrm{Pb}$, and $\mathrm{W}$. The 2-years-old stems may also be appropriate samples to detect higher levels of $\mathrm{Fe}, \mathrm{Zn}$ and $\mathrm{Pb}$.

However, more studies are needed on the plant communities that are growing on these metal-contaminated soils and tailings to evaluate their potential for biogeochemical exploration and environmental biomonitoring, but also for mine stabilization/remediation.

Acknowledgments The authors gratefully acknowledge the instrumental support of the Geosciences Centre at Coimbra University and the financial support from Portuguese Foundation for Science and Technology presented as a grant (Project PTDC/CTE-GEX/66710/ 2006). Finally, we would like to thank the anonymous reviewers and the editor for their constructive comments and helpful suggestions.

\section{References}

Aboal JR, Fernández JA, Carballeira A (2004) Oak leaves and pine needles as biomonitors of airborne trace elements pollution. Environ Exp Bot 51:215-225

Adriano D (2001) Trace Elements in Terrestrial Environments. Biogeochemistry, Bioavailability and Risks of Metals. Springer, New York, pp 219-261, 499-546, 677-705

Ávila PF, Oliveira JMS, Silva EF, Fonseca EC (2005) Geochemical signatures and mechanisms of trace elements dispersion in the area of the Vale das Gatas mine (Northern Portugal). J Geochem Explor 85:17-29

Bargagli R (1993) Plant leaves and lichens as biomonitors of natural or anthropogenic emissions of mercury. In: Markert B (ed) Plants as biomonitors: indicators for heavy metals in the terrestrial environment. VCH, Weinheim, pp 461-484

Baycu G, Tolunay D, Özden H, Günebakan S (2006) Ecophysiological and seasonal variations in $\mathrm{Cd}, \mathrm{Pb}, \mathrm{Zn}$, and $\mathrm{Ni}$ concentrations in the leaves of urban deciduous trees in Istanbul. Environ Pollut 143:545-554

Brooks R (1983) Biological methods of prospecting for minerals. Wiley, New York

Chiarenzelli J, Aspler L, Dunn C, Cousens B, Ozarko D, Powis K (2001) Multi-element and rare earth element composition of lichens, mosses, and vascular plants from the Central Barrenlands, Nunavut, Canada. Appl Geochem 16:245-270

Coşkun M (2006) Toxic metals in the Austrian pine (Pinus nigra) bark in the Thrace region, Turkey. Environ Monit Assess 121:173-179

Dmuchowski W, Gozdowski D, Baczewska AH (2011) Comparison of four bioindication methods for assessing the degree of environmental lead and cadmium pollution. J Hazard Mater 197:109-118

Favas P (2002) Restrictions to the farming use of the soils in the surroundings of an abandoned mine (Vale das Gatas Mines,
Sabrosa, Vila Real). Revista de Ciências Agrárias 25:280-292 (in Portuguese)

Fletcher WK (1981) Analytical methods in geochemical prospecting. In: Govett GJS (ed) Handbook of exploration geochemistry, vol 1. Elsevier, Amsterdam

Guéguen F, Stille P, Geagea ML, Boutin R (2012) Atmospheric pollution in an urban environment by tree bark biomonitoringpart I: trace element analysis. Chemosphere 86:1013-1019

Hooper DU, Vitousek PM (1997) The effects of plant composition and diversity on ecosystem processes. Science 277:1302-1305

Kabata-Pendias A (2010) Trace Elements in Soils and Plants, 4th edn. CRC Press, Boca Raton

Kord B, Mataji A, Babaie S (2010) Pine (Pinus eldarica Medw.) needles as indicator for heavy metals pollution. Int J Environ Sci Tech 7(1):79-84

Kovalevskii A (1979) Biogeochemical Exploration for Mineral Deposits. Amerind Publishing, New Delhi

Kuang YW, Wen DZ, Zhou GY, Liu SZ (2007) Distribution of elements in needles of Pinus massoniana (Lamb.) was uneven and affected by needle age. Environ Pollut 145:730-737

Liu Y-J, Zhu Y-G, Ding H (2007) Lead and cadmium in leaves of deciduous trees in Beijing, China: development of a metal accumulation index (MAI). Environ Pollut 145:387-390

Mani D, Sharma B, Kumar C, Pathak N, Balak S (2012) Phytoremediation potential of Helianthus anпииs $\mathrm{L}$ in sewage-irrigated Indo-Gangetic alluvial soils. Int J Phytoremediat 14:235-246

Nagaraju A, Karimulla S (2001) Geobotany and biogeochemistry of Gymnosporia montana - a case study from Nellore Mica Belt, Andhra Pradesh. Environ Geol 41:167-173

Nagaraju A, Karimulla S (2002) Accumulation of elements in plants and soils in and around Nellore mica belt, Andhra Pradesh, India—a biogeochemical study. Environ Geol 41:852-860

Nelson DW, Sommers LE, (1996) Total carbon, organic C and organic matter. In: Page AL, Miller RH, Keeney DR (eds) Methods of Soil Analysis, Part 2, 2nd. Agronomy Monograph 9. Soil Science Society of America, Madison WI, pp 961-1010

Oliva SR, Mingorance MD (2006) Assessment of airborne heavy metal pollution by aboveground plant parts. Chemosphere 65: $177-182$

Özdemir Z (2005) Pinus brutia as a biogeochemical medium to detect iron and zinc in soil analysis, chromite deposits of the area Mersin, Turkey. Chem Erde 65:79-88

Pratas J, Prasad MNV, Freitas H, Conde L (2004) Pinus pinaster Aiton (maritime pine): a reliable indicator for delineating areas of anomalous soil composition for biogeochemical prospecting of As (Arsenic), Sb (Antimony) and W (Tungsten). Eur J Miner Process Environ Protect 4:136-143

Pratas J, Prasad MNV, Freitas H, Conde L (2005) Plants growing in abandoned mines of Portugal are useful for biogeochemical exploration of arsenic, antimony, tungsten and mine reclamation. J Geochem Explor 85:99-107

Quin BF, Brooks RR (1972) The rapid determination of tungsten in soils, stream sediments, rocks and vegetation. Anal Chim Acta 58:301-309

Rodriguez JH, Wannaz ED, Salazar MJ, Pignata ML, Fangmeier A, Franzaring J (2012) Accumulation of polycyclic aromatic hydrocarbons and heavy metals in the tree foliage of Eucalyptus rostrata, Pinus radiata and Populus hybridus in the vicinity of a large aluminium smelter in Argentina. Atmos Environ 55:35-42

Salgueiro AR, Ávila PF, Pereira HG, Oliveira JMS (2008) Geostatistical estimation of chemical contamination in stream sediments: the case study of Vale das Gatas mine (northern Portugal). J Geochem Explor 98:15-21

Sawidis T, Breuste J, Mitrovic M, Pavlovic P, Tsigaridas K (2011) Trees as bioindicator of heavy metal pollution in three European cities. Environ Pollut 159:3560-3570 
Silva JJRF, Williams RJP (2001) The biological chemistry of the elements. The inorganic chemistry of life, 2nd. Oxford University Press, New York, pp 450-470

Sun FF, Wen DZ, Kuang YW, Li J, Zhang JG (2009) Concentrations of sulphur and heavy metals in needles and rooting soils of Masson pine (Pinus massoniana L.) trees growing along an urban-rural gradient in Guangzhou. China. Environ Monit Assess 154:263-274

Van Loon JC (1985) Selected methods of trace metal analysis: biological and environmental samples. Wiley, London
Walsh JN, Gill R, Thirlwall MF (1997) Dissolution procedures for geological and environmental samples. In: Gill R (ed) Modern analytical geochemistry. An introduction to quantitative chemical analysis techniques for earth, environmental and materials scientists. Longman, Essex, pp 29-40

Wittig R (1993) General aspects of biomonitoring heavy metals by plants. In: Markert B (ed) Plants as biomonitors: indicators for heavy metals in the terrestrial environment. $\mathrm{VCH}$, Weinheim, pp 3-27 